ALINE IRAMINA

\title{
EVOLUÇÃO DO REGIME INTERNACIONAL DE COMÉRCIO: DE HAVANA A MARRAKESH
}

Trabalho de Conclusão de Curso de Relações Internacionais para a Universidade de Brasília, apresentado como requisito parcial à obtenção do título de Especialista em Relações Internacionais.

Brasília 
ALINE IRAMINA

EVOLUÇÃO DO REGIME INTERNACIONAL DE COMÉRCIO: DE HAVANA À MARRAKESH

Trabalho de Conclusão de Curso de Relações Internacionais para a Universidade de Brasília, apresentado como requisito parcial à obtenção do título de Especialista em Relações Internacionais.

Orientador: Eiiti Sato

Brasília 
A Deus, aos meus pais e aos meus amigos... companheiros de todas as horas... 


\section{AGRADECIMENTOS}

A minha família, pela confiança e incentivo.

Ao meu orientador, Prof. Eiiti Sato, pelar horas de leitura, correção e compreensão.

Aos meus amigos, pela força e pelo apoio.

A todos, que direta ou indiretamente, colaboraram na execução deste trabalho. 
IRAMINA, Aline. A Evolução do Regime Internacional de Comércio: de Havana à Marrakesh. 2009. Trabalho Acadêmico de Conclusão de Curso (Especialização em Relações Internacionais) - Universidade de Brasília.

\section{RESUMO}

Apesar da Organização Mundial de Comércio (OMC), criada em $1^{\circ}$ de janeiro de 2005, ser uma instituição relativamente nova, os fundamentos de seu sistema de comércio existe há mais de sessenta anos. Estabelecido ao fim da Segunda Guerra Mundial, após o fracasso na criação da Organização Internacional de Comércio (OIC), o Acordo Geral de Tarifas e Comércio (GATT) foi o responsável por fornecer, de 1948 a 1994, as regras do sistema multilateral de comércio. O objetivo deste trabalho, assim, é apresentar as mudanças observadas no regime internacional de comércio, de Havana, em 1948, à Marrakesh, em 1994, as diferenças entre os sistemas do GATT e da OMC, além das perspectivas para a conclusão da Rodada Doha para o Desenvolvimento, lançada em 2001.

Palavras-chave: Regime Internacional de Comércio, Acordo Geral de Tarifas e Comércio (GATT), Organização Mundial de Comércio (OMC), Rodada Doha. 
IRAMINA, Aline. The Evolution of the International Trade Regime: From Havana to Marrakesh. 2009. Trabalho Acadêmico de Conclusão de Curso (Especialização em Relações Internacionais) - Universidade de Brasília.

\begin{abstract}
Although the World Trade Organization (WTO), established on January $1^{\text {st }}$ 2005 , is considered a relatively new institution, the fundamental of its trading system are more than sixty years. Established in the end of World War II, after the failed attempt to create an International Trade Organization, the General Agreement on Tariffs and Trade (GATT) was responsible to provide, from 1948 to 1994, the rules for the world trading system. Therefore, the aim of this work is to present the changes perceived in the international trade regime, from Havana, in 1948, to Marrakesh, in 1994, the differences between the GATT and the WTO systems, besides the perspectives for the conclusion of Doha Round, launched in 2001.
\end{abstract}

Key-words: International Trade Regime, General Agreement on Tariffs and Trade (GATT), World Trade Organization (WTO), Doha Round. 


\section{LISTA DE SIGLAS E ABREVIATURAS}

BIRD

ESC

FMI

GATT

GATS

MERCOSUL

NMF

OIC

OMC

ORPC

OSC

SMS

TRIMS

TRIPS

UE

UNCTAD

Banco Internacional de Reconstrução e

Desenvolvimento

Entendimento de Solução de Controvérsias

Fundo Monetário Internacional

General Agreement on Tariffs and Trade (Acordo Geral de Tarifas e Comércio)

General Agreement on Trade in Services

Mercado Comum do Sul

Nação Mais Favorecida

Organização Internacional de Comércio

Organização Mundial de Comércio

Órgão de Revisão de Política Comercial

Órgão de Solução de Controvérsias

Sistema Multilateral de Comércio

Trade-related Investment Measures

Trade-related Aspects of Intellectual Property Rights

União Européia

Conferência das Nações Unidas para o Comércio e Desenvolvimento 


\section{SUMÁRIO}

INTRODUÇÃO 09

1. REGIME INTERNACIONAL DO COMÉRCIO 12

1.1 OS REGIMES INTERNACIONAIS 12

1.2 O REGIME INTERNACIONAL DE COMÉRCIO A PARTIR DE BRETTON WOODS 14

2. PRINCÍPIOS FUNDAMENTAIS DO SISTEMA MULTILATERAL DE COMÉRCIO 21

2.1 O PRINCÍPIO DA NÃO-DISCRIMINAÇÃO 21

2.2 OUTROS PRINCÍPIOS FUNDAMENTAIS 23

3. A EVOLUÇÃO DO REGIME INTERNACIONAL DO COMÉRCIO 25

3.1 INSTAURAÇÃO DO ACORDO GERAL DE COMÉRCIO E TARIFAS (GATT) 26

3.1.1 Estrutura Institucional do GATT 27

3.1.1.1 Sistema de Solução de Controvérsias do GATT 28

3.1.2 As Rodadas de Negociação do GATT 29

3.1.2.1 Rodada do Uruguai__ 34

3.2 CRIAÇÃo dA ORGANIZAÇÃo MUNDIAL DO COMÉRCIO (OMC)__ 36

3.2.1 Estrutura Institucional da OMC _ 37

3.2.2.1 Sistema de Solução de Controvérsias da OMC__ 39

3.3.2 Conferências Ministeriais da OMC___ 42

3.2.3 Rodada Doha para o Desenvolvimento___ 44

3.3 PRINCIPAIS DIFERENÇAS ENTRE O GATT E A OMC _ 47

CONCLUSÃO__ 49

BIBLIOGRAFIA

ANEXOS__ 54 


\section{INTRODUÇÃO}

Uma nova ordem econômica internacional foi estabelecida ao final da Segunda Guerra Mundial, na Conferência de Bretton Woods, em 1944, cujos princípios, no entanto, já haviam sido declarados em 1941, na Carta do Atlântico. Essa nova ordem, que efetivamente ganhou forma mais definida nos anos que se seguiram, favoreceu o aumento do fluxo comercial e a integração econômica entre os países do globo, o que resultou em grandes mudanças nas relações econômicas internacionais. Pode-se dizer que, sob a liderança dos Estados Unidos, estabeleceu-se um conjunto de regimes com princípios, normas, regras e instituições que pressupunham processos decisórios e diferentes papéis para os países que passaram a definir, em última instância, as condições de inserção das nações na ordem econômica internacional. $\mathrm{Na}$ esfera do comércio, embora não tenha sido objeto de deliberação na reunião de Bretton Woods, pode-se incluir nessa nova ordem o Acordo Geral de Tarifas e Comércio (GATT), negociado em 1947 e que, após sofrer diversas mudanças durante as quase cinco décadas em que vigorou, foi, por fim, substituído, em 1995, pela Organização Mundial de Comércio $(\mathrm{OMC})$.

Dessa forma, apesar de a OMC ser uma instituição relativamente nova, os fundamentos do sistema multilateral de comércio, existe há mais de sessenta anos. Com efeito, a partir de 1948, por meio de rodadas de negociação e outros procedimentos mais rotineiros, o GATT foi responsável por fornecer as principais regras orientadoras do sistema de comércio. As primeiras cinco rodadas de negociação comercial do GATT trataram basicamente de reduções tarifárias, mas as rodadas subseqüentes, em vista dos avanços significativos da integração econômica internacional, passaram a ampliar a competência dos acordos negociados, incluindo outras áreas como antidumping e barreiras não-tarifárias. A última e maior rodada levada a termo - a Rodada do Uruguai - resultou na criação da OMC. Para compreender o regime de comércio atual, sob a égide da OMC, é necessário, desse modo, conhecer melhor a história do seu predecessor, o 
GATT.

Assim, este trabalho procura discutir algumas das principais mudanças ocorridas no regime internacional de comércio durante o período que se estende desde a Conferência de Havana, em 1948, até o lançamento da Rodada Doha, em 2001. Para esse propósito, será necessário re-visitar os princípios fundamentais que regem o sistema multilateral de comércio do GATT/OMC e também as discussões referentes à importância do GATT na liberalização do comércio internacional. Serão também objeto de breve análise alguns dos resultados obtidos nas Rodadas de Negociação do GATT e como eventuais divergências entre países desenvolvidos e em desenvolvimento foram conduzidas dentro do contexto do comércio mundial. Por fim, serão avaliadas algumas perspectivas em relação à conclusão da Rodada Doha considerando-se o papel da OMC na atual conjuntura internacional e as principais diferenças entre os regimes de comércio quando centrado no GATT e, depois, na OMC.

O propósito deste trabalho, considerando-se as limitações inerentes a uma monografia, tem por objetivo apresentar uma visão de conjunto da evolução do atual regime internacional de comércio, que se iniciou após o fim da Segunda Guerra Mundial, desde a instauração do Acordo Geral de Comércio e Tarifas (GATT), em 1947, até o lançamento da Rodada Doha, em 2001, a primeira rodada de negociações sob os auspícios da OMC. Não se pretende buscar originalidade, mas principalmente reunir conhecimentos relevantes referentes a um dos fenômenos mais relevantes do universo das relações internacionais que é a consolidação do sistema multilateral de comércio em âmbito efetivamente global. Dessa forma, no primeiro capítulo trataremos da base conceitual que ajuda a compreender a formação de um regime internacional para o comércio. Ao definir o conceito de regimes internacionais e ao traçar, brevemente, a evolução do regime internacional de comércio desde a sua criação em Bretton Woods o trabalho torna explícita a forma como os conhecimentos foram organizados. No segundo capítulo, são discutidos os princípios fundamentais do sistema multilateral de comércio do GATT/OMC, dando o devido destaque ao 
princípio da não-discriminação. Por fim, no terceiro capítulo serão abordadas as principais características do sistema do GATT e da OMC e as principais diferenças entre esses dois sistemas. Ao final segue-se uma breve conclusão indicando algumas interpretações possíveis para o cenário do comércio internacional. Obviamente, pelas próprias limitações do escopo do trabalho não serão tratados os aspectos decorrentes do desencadeamento da atual crise econômica internacional. 


\section{REGIME INTERNACIONAL DE COMÉRCIO}

Desde o imediato pós-guerra até os dias atuais, houve uma grande evolução do regime multilateral de comércio. As mudanças na economia mundial, durante todo esse período, influenciaram diretamente as transformações ocorridas no regime.

Atualmente, o regime internacional de comércio centraliza-se na Organização Mundial de Comércio (OMC), no entanto, para entender essa instituição, é necessário saber também um pouco sobre o seu predecessor, o GATT. De fato, a carta da OMC deixa claro a importância da história do GATT para a organização, ao prescrever (no Artigo 16) que a OMC deverá guiar-se pelas decisões, procedimentos e praticas costumeiras seguidas pelas partes contratantes do GATT 1947 e pelas instituições estabelecidas na estrutura do GATT 1947 (JACKSON, 1997).

Tendo em vista que as regras e as normas nas relações internacionais são estruturadas e interpretadas pelas "práticas costumeiras", inclusive, pelas performances de suas instituições, saber a história e as práticas institucionais e normas internacionais anteriores são de extrema importância para o melhor entendimento do regime atual.

\subsection{Regimes Internacionais}

O conceito de regimes internacionais está, em sua essência, associado ao bem-estar comum e a uma necessidade de estabelecer-se uma ordem nas relações internacionais, seja por meio de tratados e acordos bilaterais e regionais, seja por meio de organismos internacionais formalmente constituídos (SANTIAGO, 2005).

Segundo Krasner, um regime internacional é um "conjunto de princípios, normas, regras e procedimentos de tomada de decisões em torno dos quais convergem as expectativas dos atores em uma área específica" (KRASNER, 1983, p. 01-21). Para o autor, os regimes podem ser 
pensados como variáveis intervenientes que intermedeiam a relação entre fatores casuais (como interesse próprio, poder político e valores difundidos) e os resultados e comportamentos alcançados.

Nesse sentido, para liberais como Keohane e Nye, os regimes são um "número" de acordos governamentais que inclui um "conjunto" de regras, normas e procedimentos que regulariza o comportamento e controla os seus efeitos em uma determinada área. Sendo o propósito dos regimes internacionais, o de facilitar acordos.

$\mathrm{Na}$ visão dos liberais, desse modo, os regimes internacionais facilitam uma maior cooperação internacional, o que permite, aos Estados, superar os obstáculos à colaboração impostos pela estrutura anárquica do meio internacional.

Para os realistas, como Hedley Bull, que entendem o meio internacional como uma anarquia onde se observa uma constante política de poder, os regimes internacionais são importantes para ajudarem a assegurar a obediência às normas, formulando-as, comunicando-as, administrando-as, reforçando-as, interpretando-as, legitimando-as e adaptando-as.

Contudo, para a escola realista, os regimes não têm muita importância no sistema internacional, ou para alguns como Susan Strange, "os regimes, se pode ser dito que eles existem, têm pouco ou nenhum impacto" (KRASNER, 1983, p. 01-21), uma vez que, para eles, os acordos internacionais de um determinado regime são muito facilmente desfeitos quando a "balança do poder" ou a percepção de interesse nacional, ou ambos, mudam entre os Estados que os negociaram.

Diferentemente da posição realista, na grotiana, seguida por Raymond Hopking, Donald Puchala e Oran Young, rejeita-se a noção de sistema internacional composto apenas por Estados soberanos e limitado pela balança do poder e sugere que as elites são os atores práticos das relações internacionais e que eles agem dentro de uma rede de comunicações, incorporando normas, regras e princípios que ultrapassam as fronteiras nacionais (KRASNER, 1983). Para esses autores, os regimes 
existem em todas as áreas das relações internacionais, até mesmo naquelas em que há uma grande rivalidade de poder, e que normalmente são apontadas como exemplos claros de anarquia.

As diferentes percepções dos regimes internacionais por essas escolas teóricas (liberal, realista, grotiana), segundo Hansclever, Mayers e Rittberger, encontram-se, assim, no grau de institucionalismo de cada uma delas, uma vez que a efetividade e a força dos regimes internacionais estão relacionadas, respectivamente, à proporção que seus membros se submetem a regras e normas e ao poder das instituições internacionais face os desafios externos (SANTIAGO, 2005).

No caso do regime internacional do comercio, especificamente, uma maior compreensão acerca dos sistemas do GATT e, mais recentemente, da OMC são de extrema importância para o seu estudo, uma vez que é por meio do funcionamento e da evolução desses sistemas é que se construiu e, ainda, se constrói esse regime internacional.

\subsection{O Regime Internacional de Comércio desde Bretton Woods}

A ordem econômica internacional pós-Segunda Guerra Mundial consagrou a supremacia econômica norte-americana e, assim como a pax britannica do século XIX, estabeleceu uma ordem liberal e multilateral com regimes internacionais fortes.

O regime internacional de Bretton Woods, criado a partir da Conferência de Bretton Woods, realizada em 1944, nos Estados Unidos, definiu uma nova ordem econômica internacional, dirigida pelos Estados Unidos, que ao lançar as bases do sistema financeiro e comercial pósSegunda Guerra Mundial, criou as principais organizações governamentais relacionados às relações econômicas internacionais: o Fundo Monetário Internacional (FMI), o Banco Internacional de Reconstrução e Desenvolvimento (BIRD) ou Banco Mundial e - devido ao fracasso na 
criação da Organização Internacional do Comércio -, posteriormente, o Acordo Geral de Comércio e Tarifas (GATT).

A criação da Organização Internacional do Comércio (OIC), apesar de prevista na Conferência de Bretton Woods e na Carta de Havana (1947), nunca se materializou, dessa forma, o GATT, assinado em 1947, de um acordo temporário foi transformado no principal fórum de negociações sobre comércio internacional, com a característica de sistema de comércio de regras bem definidas, baseado nos princípios do multilateralismo, do livre-comércio, da não discriminação, da reciprocidade.

O regime de comércio internacional do GATT, no entanto, por tratar basicamente, na sua origem, de uma área do comércio internacional (as barreiras comerciais), tinha o seu âmbito de responsabilidades drasticamente limitado em comparação ao que seria o da Organização Internacional do Comércio. O texto básico de 1947 foi, no entanto, ampliado e modificado por novos códigos e acordos, interpretações, waivers, relatórios, panels e decisões do Conselho Geral do GATT.

A Rodada Kennedy, entre 1963 e 1967, significou o início de uma nova etapa no GATT, a partir dessa rodada, novos temas passaram a ser discutidos no âmbito do GATT, como barreiras comerciais nãotarifárias e medidas antidumping. Pela primeira vez, a Comunidade Européia participou nas negociações como um bloco. Além disso, nessa rodada, aprofundou-se a percepção dos países em desenvolvimento quanto ao não atendimento de seus interesses nas negociações.

O sistema do GATT, nas quase cinco décadas em que vigorou, foi determinante para uma diminuição das barreiras comerciais e para uma maior liberalização do comércio internacional, oscilando entre momentos de maior liberalização (ex: década de 60) e momentos de maior protecionismo (ex: década de 70) por parte dos Estados. Até o início da década de 70 , o regime internacional de comércio centrou-se basicamente no GATT. 
A década de 1970, porém, foi caracterizada por grandes mudanças na economia mundial. O Japão e a Comunidade Européia consolidam, nesse período, suas posições como concorrentes dos EUA (VALLS, 1997, p. 06). Em 1971, o presidente americano Richard Nixon cancela a conversibilidade dólar-ouro estabelecida no acordo de 1944, suspendendo o sistema de Bretton Woods. As grandes transformações que se observaram, a partir dessa década, seja pela modernização dos fatores de produção, sejam pelas crises iniciadas nesse período tornaram o regime do GATT, desse modo, muito mais complexo.

A Rodada Tóquio, entre 1973 e 1979, foi realizada, assim, em um quadro de grandes mudanças na economia mundial. A proposição de novos problemas - como agricultura e salvaguardas -, nas negociações da Rodada Tóquio e o neoprotecionismo das economias desenvolvidas, induziram ao questionamento dos princípios e da estrutura do GATT.

Foi somente na década de 1980, contudo, que se observou uma possível "falência" do GATT. A recessão econômica, os processos de regionalização e à proliferação, pelos países desenvolvidos, de práticas protecionistas, privilegiando relações bilaterais e práticas discriminatórias, passaram a comprometer a credibilidade e a efetividade do GATT. Além da onda protecionista, outros movimentos, como a globalização da economia e o crescimento do fluxo de capitais e da importância do comércio de serviços para muitos países, reforçaram a percepção de que as regras multilaterais de comércio vigentes eram insuficientes para dar conta da nova realidade do comércio internacional. "As regras multilaterais, do GATT, continuavam, na prática, mesmo assim com exceções, restritas ao comércio de bens manufaturados" (REGO, 1996, p. 06).

Esse complexo cenário internacional das décadas de 1970 e 1980 levou, em 1986, ao lançamento da mais ampla e ambiciosa rodada de negociações de todo o pós-guerra: a Rodada do Uruguai. Na Rodada do Uruguai, ainda no âmbito do GATT, entre 1986 e 1993, após longas e árduas negociações, definiu-se, além da criação da Organização Mundial de 
Comércio (OMC), as novas regras a serem observadas no jogo do comércio internacional. "Os países em desenvolvimento, particularmente o Brasil, tiveram uma participação mais ativa nessas negociações do que em qualquer uma das outras realizada sob o sistema do GATT" (REGO, 1996, 02).

Durante a Rodada do Uruguai, novos temas foram incluídos nas discussões sobre comércio multilateral: políticas ambientais, condições e normas de trabalho (Labor Standards), políticas de investimentos, políticas de concorrência, imigração, questões monetárias, comércio e desenvolvimento (REGO, 1996)

A Ata da Rodada do Uruguai estabeleceu um novo Acordo Geral de Tarifas e Comércio (GATT 94), o Acordo Geral sobre o Comércio de Serviços (GATS), o Acordo sobre Investimentos (TRIMS), o Acordo sobre Direitos de Propriedade Intelectual (TRIPS), além de acordos destinados a regulamentar procedimentos de solução de controvérsias, medidas antidumping, medidas de salvaguarda, medidas compensatórias, valoração aduaneira, licenciamento, procedimentos e etc.

Os resultados da Rodada do Uruguai foram subscritos em 15 de abril de 1994, em Marrakesh, por mais de uma centena de países (Tratado de Marrakesh). De modo geral, a Rodada do Uruguai, aumentou substancialmente a obrigação dos países de praticar mais políticas comerciais liberalizantes. Essa Rodada representou um grande aprofundamento do regime internacional de comércio e foi, talvez, tão significante quanto à criação do próprio GATT (MACRORY et al, 2005). A partir de 2005, a administração do sistema multilateral de comércio passou a ser da OMC. Extinguia-se, assim, o regime internacional de comércio do GATT, e iniciava-se o da OMC, cujos objetivos principais pautam-se na busca do livre comércio e na igualdade entre os países.

A criação da OMC veio completar a arquitetura mundial da "nova ordem econômica internacional" delineada no fim da Segunda Guerra Mundial, com a criação do FMI e do BIRD, que havia ficado incompleta 
devido a não materialização da OIC de 1948. A OMC, diferentemente do GATT, constitui-se, assim, em uma organização permanente, com personalidade jurídica própria, com o mesmo status jurídico e internacional das duas instituições de Bretton Woods - FMI e Banco Mundial.

A OMC baseia-se em princípios de comércio internacional desenvolvidos ao longo dos anos e consolidados em acordos comerciais estabelecidos em oito rodadas de negociações multilaterais no âmbito do GATT. O princípio fundamental do sistema multilateral de comércio, sob os auspícios da OMC, é o da não-discriminação. Na OMC, as negociações seguem o princípio do single undertaking - "compromisso único" - que obriga a todos os membros a concordarem com todos os temas negociados e impede que os países escolham apenas os acordos de seus interesses.

Destacam-se, na nova organização: o novo sistema vinculante de solução de controvérsias que operacionalizou o conceito de arbitramento compulsório em disputas comerciais entre Estados-membros, assegurando a eles melhor proteção de seus direitos; o acordo de liberalização comercial estabelecido em matérias de agricultura e de têxteis, duas áreas críticas para países em desenvolvimento e para outros países exportadores de produtos primários, que foram talhadas das negociações no GATT por quase todo o período pós-guerra; e os acordos em novas áreas, como serviços e propriedade intelectual, que expandiram substancialmente 0 alcance do velho acordo geral (MACRORY et al., 2005).

A primeira tentativa de lançar uma rodada abrangente de negociações multilaterais sobre o comércio, no âmbito da OMC, fracassou na Conferência Ministerial de Seattle, em novembro de 1999. Durante a terceira reunião ministerial da OMC, pretendia-se lançar a Rodada do Milênio, no entanto, manifestações contra a OMC e contra a globalização (que ficaram conhecidas como Batalha de Seattle ou N-30), reunindo entre 40 mil e 100 mil pessoas - entre as quais ecologistas, anarquistas, trabalhadores sindicalizados, estudantes e pacifistas - levaram a queda dessa rodada. 
O fracasso da Conferência Ministerial de Seattle, desse modo, colocou em risco o futuro do sistema multilateral de comércio e a própria OMC, como instituição, e deixou uma série de desafios a serem enfrentados pelos membros da organização. A era do antigo GATT acabou em Seattle, pois, o processo de negociação envolvendo pequenos grupos formado pelos membros mais influentes - tornou-se inaceitável. Ademais, tornaram-se indispensáveis à continuidade e ao funcionamento da OMC a transparência dentro da organização, perante a sociedade civil e, mais importante, o contrabalanço, nas negociações, dos interesses dos países desenvolvidos e dos países em desenvolvimento. A reunião de Seattle ficará marcada como um grande divisor de águas na história da OMC.

Após Seattle, era necessária uma nova rodada de negociações para a liberalização do comércio mundial. Sob o impacto dos ataques de 11 de setembro e em um cenário econômico de desaceleração global, a realização da Conferência Ministerial de Doha, em 2001, tinha 0 explicito objetivo de dar início a uma nova rodada, o que foi concretizado com o lançamento da Agenda de Desenvolvimento de Doha, ao término da reunião. Definiu-se que, nessa nova rodada de negociações, os interesses dos países em desenvolvimento e/ou de menor desenvolvimento relativo seriam levados em consideração. A intenção declarada da rodada era tornar as regras de comércio mais livres para esses países. A agricultura seria, assim, o tema central da Rodada Doha. A Rodada Doha foi lançada com previsão de término em 01 de janeiro de 2005, no entanto, até a presente data (abriV2009), não foi concluída e nem tem previsão de conclusão.

Na Conferência Ministerial de Cancun, em 2003, buscou-se planejar um acordo concreto sobre os objetivos da Rodada Doha, porém, a reunião fracassou diante da discussão entre os países membros sobre subsídios agrícolas e acesso a mercados. A divisão entre os países desenvolvidos e os em desenvolvimento ficaram evidentes nos assuntos ligados à agricultura. O grande destaque, no entanto, dessa reunião, foi a formação, pelos países em desenvolvimento, entre eles o Brasil, de um 
grupo - o G-201 -, que nasceu com o objetivo de tentar, como de fato o fez, impedir um resultado predeterminado em Cancun e de abrir espaços para as negociações em agricultura. O G-20 consolidou-se, assim, como interlocutor essencial e reconhecido nas negociações agrícolas.

Após Cancun, houve ainda os encontros em Genebra (2003) e Paris (2004) e a Conferência de Hong Kong, em 2005, porém, não se chegou a um consenso mundial a respeito da abertura comercial. A Rodada Doha, dessa forma, continua sem previsão de conclusão e, conseqüentemente, o futuro do regime internacional de comércio, sob a égide da OMC, em aberto.

Em vista do exposto neste capítulo, é possível concluir que há um regime internacional de comércio - um conjunto de princípios, normas, regras que regulam o comércio internacional - e que esse regime atual, sob a égide da OMC, teve início, ainda no período pós-guerra, com a instauração do GATT, em 1948.

Pode-se concluir, ainda, que o atual regime de comércio, centrado na OMC, apesar de originar-se do GATT, foi constituído de forma a suprir as suas deficiências e ser, dessa forma, mais eficiente e mais justo na liberalização do comércio mundial. A indefinição na resolução da Rodada Doha, contudo, põe em risco esse novo sistema.

\footnotetext{
${ }^{1}$ O G-20 tem uma vasta e equilibrada representação geográfica, sendo atualmente integrado por 23 Membros: 5 da África (África do Sul, Egito, Nigéria, Tanzânia e Zimbábue), 6 da Ásia (China, Filipinas, Índia, Indonésia, Paquistão e Tailândia) e 12 da América Latina (Argentina, Bolívia, Brasil, Chile, Cuba, Equador, Guatemala, México, Paraguai, Peru, Uruguai e Venezuela). Disponível em < http://www.g-20.mre.gov.br/history port.asp>. Acesso em: 22 de março de 2009.
} 


\section{PRINCÍPIOS FUNDAMENTAIS DO SISTEMA MULTILATERAL DE COMÉRCIO}

Os acordos do GATT/OMC, por se tratarem de textos legais que abrangem uma variedade de atividades - como agricultura, têxteis, propriedade intelectual, compras governamentais, normas industriais - são longos e complexos. Porém, uma quantidade de princípios simples e fundamentais encontra-se disposto nesses documentos: não-discriminação, livre-comércio, previsibilidade, concorrência leal e tratamento preferencial e diferenciado para os países em desenvolvimento. Esses princípios, juntamente com os princípios da transparência e da reciprocidade, são a base do sistema multilateral de comércio do GATT/OMC².

\subsection{Princípio da Não-Discriminação}

A não-discriminação é o princípio fundamental do sistema multilateral de comércio e está expresso nos acordos do GATT/OMC por meio de duas regras: as cláusulas da nação mais favorecida (NMF) e do tratamento nacional (Arts. I e III do GATT) (REGO, 1996).

A cláusula da nação mais favorecida ("most favorable nation"), dado sua importância, encontra-se no art. I do GATT e dispõe, basicamente, que as nações devem ser tratadas igualmente. Determina-se por esse princípio que no comércio mundial não deve haver discriminação, assim, qualquer benefício ou restrição adotado por um determinado país em relação a outro, no tocante à sua política de comércio exterior, será automaticamente estendido aos demais países membros da OMC.

Há, contudo, algumas exceções ao princípio da nação mais favorecida, relacionadas, sobretudo, a acordos de integração econômica -

\footnotetext{
${ }^{2}$ WTO. Understandig WTO. Disponível em: $<$ www.wto.org/english/thewto e/whatis e/tif e/understanding e.pdf $>$. Acesso em: $02 \mathrm{de}$ abril de 2009.
} 
tais como área de livre comércio, união aduaneira e mercado comum - e a preferências tarifárias que podem ser concedidas pelos países desenvolvidos a países em desenvolvimento ${ }^{3}$ (REGO, 1996). Apesar de previstas nos acordos da OMC, essas exceções, no entanto, não deixam de causar controvérsias entre os países-membros da organização, como no caso do acesso ao mercado de bananas da União Européia (UE), o litígio mais longo na história da $\mathrm{OMC}^{4}$.

Já a cláusula do tratamento nacional, prevista no art. III do GATT, determina que os produtos importados e locais tenham tratamentos iguais, assim, os bens importados devem receber o mesmo tratamento concedido aos bens equivalentes de origem nacional - pelo menos depois de terem entrado no país. Esse princípio baseia-se no princípio da igualdade e busca assegurar condições iguais de concorrência a todos os produtos, independente de sua origem.

O princípio do tratamento nacional aplica-se, no entanto, somente após a entrada do produto no mercado nacional. Desse modo, a cobrança de imposto de importação sobre produtos estrangeiros não viola

\footnotetext{
${ }^{3}$ Esse sistema generalizado de preferências, que permite que países em desenvolvimento recebam tratamento especial no que se refere ao acesso aos mercados dos países desenvolvidos, foi aceito formalmente pelo GATT quando da conclusão da Rodada Tóquio, em 1979.

4 "A banana, fruta mais consumida no mundo desenvolvido, é o produto com o litígio mais longo na história da Organização Mundial do Comércio (OMC). Por conta da banana, os países latino-americanos litigam com a União Européia (UE) no Órgão de Solução de Controvérsias da OMC (OSC) desde 1993. (...) No que tange à importação de bananas, a política comunitária da UE buscou preservar os compromissos assumidos por alguns de seus Membros com países da África, Caribe e Pacífico (grupo ACP) e seus territórios ultramar. De modo geral, tais compromissos asseguravam acesso preferencial das bananas cultivadas nessas regiões ao mercado do bloco europeu. Em junho de 1993, criou-se o Mercado Comum de Bananas, cerne das disputas comerciais que envolveram a UE na OMC". (ICTSD. Bananas: Uma década na Agenda da OMC. Disponível em: < http://ictsd.net/i/news/4409/>. Acesso em: 03 de abril de 2009.

Em dezembro de 2008, "a instância mais alta da OMC proferiu (...) uma decisão contrária à União Européia (UE) relativa à longa controvérsia com os países latino-americanos e os Estados Unidos da América (EUA) acerca do comércio de bananas. O Órgão de Apelação manteve a recomendação de adequação ao sistema multilateral emitida pelo painel, que havia reconhecido o caráter discriminatório do regime de importação de bananas da UE". (ICTSD. Bananas: OMC condena regras de importação da UE e Equador ameaça vetar Doha se a questão não for resolvida. Disponível em: < http://ictsd.net///news/pontesquinzenal/35526/>. Acesso em: 03 de abril de 2009.
} 
esse princípio. Aplica-se a cláusula do tratamento nacional não só a produtos, como também a serviços e a itens relacionados à propriedade intelectual.

Assim, "enquanto a cláusula de nação mais favorecida busca evitar a existência de discriminação entre os diversos países fornecedores de um determinado produto, a cláusula de tratamento nacional procura impedir a discriminação do produto importado em relação aos produtos nacionais" (REGO, 1996, p. 12). Tanto o princípio da nação mais favorecida, quanto o do tratamento nacional estão previstos não só no GATT, como também no GATS e no TRIPS - juntos, esses três acordos cobrem as três principais áreas de comércio administradas pela OMC.

\subsection{Outros Princípios Fundamentais}

Nos termos dos acordos do GATT/OMC, além de nãodiscriminatório, o sistema de comércio deve ser livre, previsível, mais competitivo (desencorajando práticas desleais) e mais benéfico para os países menos desenvolvidos. Deve-se, dessa forma, não só abandonar, por meio de negociações, barreiras comerciais, como também ter maior previsibilidade e transparência sobre as condições em que se opera o comércio internacional, desencorajar práticas desleais - como subsídios de exportação e práticas de dumping -, e dar aos países menos desenvolvidos mais tempo para ajustar-se, maior flexibilidade e privilégio especiais ${ }^{5}$.

São também fundamentais para o sistema de comércio do GATT/OMC, os princípios da transparência e da reciprocidade. Enquanto pelo princípio da transparência impõe-se aos países o dever de informar, de forma ampla, o conteúdo da política comercial adotada, pelo princípio da reciprocidade espera-se que os países façam concessões em troca de benefícios obtidos de outros parceiros.

\footnotetext{
${ }^{5}$ WTO. Understandig WTO. Disponível em: $<$ www.wto.org/english/thewto e/whatis e/tif e/understanding e.pdf $>$. Acesso em: 02 de abril de 2009. p. 10.
} 
Na aplicação do princípio da reciprocidade, no entanto, há uma diferença marcante entre o GATT e a OMC. No GATT, os países em desenvolvimento estavam na prática isentos desse tipo de princípio, pois, beneficiavam-se das concessões bilaterais realizadas entre os países desenvolvidos, com a aplicação da cláusula da nação mais favorecida (operavam no GATT como free riders). Na OMC, a situação é diferente, pois o fato de um país ser membro já o torna signatário da maioria dos acordos, com seus direitos e benefícios, de um lado, e suas obrigações e seus custos, de outro (GONÇALVES, 2000).

Por meio da aplicação desses princípios busca-se não só encorajar livre-comércio mundial, como também torná-lo mais justo e eficiente, de forma a beneficiar todos os países, principalmente, os países menos desenvolvidos.

Pelo estudo dos princípios fundamentais do sistema multilateral de comércio do GATT/OMC, pode-se concluir, desse modo, que esse sistema, apesar de todos seus defeitos, tem, desde seu início, como objetivo principal a promoção do livre-comércio, em base seguras, de modo a contribuir para o crescimento, desenvolvimento econômico e bem estar dos povos. 


\section{EVOLUÇÃO DO REGIME INTERNACIONAL DE COMÉRCIO: DE}

\section{HAVANA À MARRAKESH}

"A criação da Organização Mundial de Comércio (OMC), em $1^{\circ}$ janeiro de 1995, marcou a maior reforma do comércio internacional, desde o fim da Segunda Guerra Mundial', organização para o comércio internacional, projeto que havia sido "abandonado" após o fracasso na criação da Organização Internacional de Comércio (OIC).

Grande parte da história, nesses 47 anos - da instauração do GATT, em 1948, à criação da OMC, em 1995 -, foi escrita em Genebra. Mas, traçou-se, também, um percurso que cobriu continentes: desde o hesitante início, em 1948, em Havana (Cuba), via Annecy (França), Torquay (Reino Unido), Tóquio (Japão), Punta Del Este (Uruguai), Montreal (Canadá), Bruxelas (Bélgica), até finalmente Marrakesh (Marrocos), em 1994. Durante todo esse período, o regime de comércio ficou sob a égide do GATT, que ajudou a estabelecer um forte e próspero sistema multilateral de comércio, que se tornou mais liberal, a cada rodada de negociação comercial realizada ${ }^{7}$.

Assim, apesar da OMC ter sido criada, em 1995, o seu sistema de comércio existe há mais de meio século. Desde 1948, o Acordo Geral de Tarifas e Comércio (GATT) fornece as normas para esse sistema. De Havana (1948) a Marrakesh (2004) houve, portanto, grandes mudanças no regime internacional de comércio.

\footnotetext{
${ }^{6}$ WTO. Disponível em < http://www.wto.org/english/thewto e/whatis e/tif e/fact4 e.htm>. Acesso em: 23 de março de 2009. p. 17.

${ }^{7}$ WTO. Disponível em < http://www.wto.org/english/thewto e/whatis e/tif e/fact4 e.htm>. Acesso em: 23 de março de 2009. p. 17.
} 


\subsection{Instauração do Acordo Geral de Comércio e Tarifas (GATT)}

O Acordo Geral de Comércio e Tarifas (GATT), apesar de não constituído na Conferência de Bretton Woods, é conseqüência dela. Juntamente com o Fundo Monetário Internacional (FMI) e o Banco Mundial, o GATT integrou as instituições do sistema de Bretton Woods, que foram criadas para regular as relações econômicas internacionais no período pósguerra.

O acordo foi assinado por 23 países, entre eles o Brasil, durante a Rodada Genebra, em 1947, a primeira das grandes rodadas de negociações multilaterais de comércio. Em vista do fracasso na criação da Organização Internacional do Comércio (OIC) - devido, em grande parte, a não ratificação da Carta de Havana pelo Congresso americano - o GATT de um acordo provisório, tornou-se o instrumento que, de fato, regulamentou o comércio internacional por mais de quatro décadas.

O GATT incorporou muitas das provisões da OIC, contidas na Carta de Havana, e, apesar de nunca ter perdido seu caráter de acordo provisório e nem ter adquirido personalidade jurídica própria, adquiriu progressivamente atribuições de uma organização internacional.

O principal objetivo do GATT, quando de sua instauração, era a diminuição das barreiras comerciais e a garantia de acesso mais eqüitativo aos mercados por parte de seus signatários. Seus principais idealizadores - Estados Unidos e Grã-Bretanha - acreditavam que a cooperação comercial não só evitaria a repetição da onda protecionista que marcou os anos 30, como também aumentaria a interdependência entre os países e ajudaria a reduzir os riscos de uma nova guerra mundial (REGO, 1996 apud KOSTECKI et al, 1995).

A formação do GATT, em 1947, foi pautada em três valores principais: restrição e/ou eliminação de práticas intervencionistas governamentais, a multilateralização das relações políticas e comerciais dos Estados e a liberalização do comércio mundial. Em suma, esses três valores 
apontavam para a formação de um conjunto de regras que viabilizariam a ordenação do comércio mundial em bases multilaterais e liberais e, na qual, práticas restritivas e discriminatórias estariam ausentes.

Após a Rodada Genebra de negociações multilaterais em 1947, foram realizadas mais sete sob a coordenação do GATT: Rodada Annecy (1949), Rodada Torquay (1950/51), segunda Rodada Genebra (1955/56), Rodada Dillon (1960/61), Rodada Kennedy (1963/67), Rodada Tóquio (1973/79) e Rodada Uruguai (1986/93) (REGO; 1996; p. 06). Todas essas rodadas foram determinantes para a ampla liberalização do comércio mundial, verificada nas mais de quatro décadas do sistema de comércio centralizado no GATT.

Assim, apesar do GATT ser, em sua origem, um acordo provisório com limitado campo de ação, o seu sucesso em promover e assegurar a liberalização de grande parte do comércio mundial é incontestável ${ }^{8}$.

\subsubsection{Estrutura Institucional do GATT}

A Estrutura do GATT era formada pelo Secretariado (Diretor Geral), pela Assembléia das partes contratantes, pelo Conselho de Representantes e pelos Comitês. O órgão supremo do GATT era a Assembléia dos Países Signatários, a qual se reunia anualmente.

O processo de decisão do GATT era usualmente por consenso, não por voto, mas quando a opção do voto surgia cada membro tinha direito a um voto e as decisões eram obtidas por maioria simples. No caso de autorizações para que determinados Estados pudessem ignorar certas obrigações do acordo era necessário, no entanto, o voto de dois terços dos membros, sendo que a maioria compreendesse mais da metade

\footnotetext{
${ }^{8}$ WTO. Understandig WTO. Disponível em: $<$ www.wto.org/english/thewto e/whatis e/tif e/understanding e.pdf $>$. Acesso em: 02 de abril de 2009.
} 
dos países signatários. A modificação de cláusula de nação mais favorecida era possível somente por unanimidade dos votos (ZANON, 1999).

Entre sessões da Assembléia dos Países Signatários, o Conselho de Representantes, composto de representantes de todos os países membros, também chamado de Conselho do GATT, estava autorizado em agir em ações de rotina ou até em circunstâncias urgentes. O conselho se reunia, em geral, mensalmente.

Outros órgãos importantes na estrutura do GATT eram os comitês. Entre os Comitês mais importantes estavam: o Comitê sobre Comércio e Desenvolvimento, que tratava de questões de especial interesse dos países em desenvolvimento e o Comitê sobre produtos Têxteis, compostos pelos signatários do Acordo Multilateral sobre Fibras.

"Comitês Ad Hoc eram criados esporadicamente para resolução de questões passageiras, ou para analisarem tópicos que seriam decididos posteriormente pelos membros. Painéis de Conciliação eram criados freqüentemente para lidar com a resolução de disputas ou controvérsias entre membros determinados" (ZANON, 1999, p. 05).

A Secretaria do GATT tinha sede em Genebra e era o órgão administrativo do GATT. O Diretor Geral comandava o secretariado, que tinha papel fundamental no desenvolvimento do comércio internacional, a medida que coletava estatísticas e servia de local de consulta para os membros.

\subsubsection{Sistema de Solução de Controvérsias do GATT}

O art. XXIII do Acordo Geral de Tarifas e Comércio regulamentava o "sistema" de solução de controvérsias do GATT. As consultas realizadas entre as partes envolvidas na disputa eram a principal forma de solução de controvérsias, no âmbito do GATT. A partir de 1955, os painéis também começaram a ser usados para análise das controvérsias surgidas entre as partes contratantes. Assim, se as consultas não tivessem 
êxito, instaurava-se o painel, formado por três peritos, que após a análise da discussão, remetiam suas conclusões ao Conselho do GATT para discussão e votação.

Havia, no entanto, a necessidade de um consenso positivo, ou seja, da aprovação de todos os membros, para a adoção de relatórios do painel e para a implementação das decisões do conselho. A dificuldade na aplicação dessas medidas era assim, o maior problema encontrado no sistema de solução de controvérsias do GATT, pois, era necessário até mesmo o consenso do Estado contra o qual seriam adotadas as medidas, o que tornava o sistema inócuo.

Junto ao consenso positivo, a falta de prazos para a realização das etapas dos procedimentos era outro problema existente no sistema de solução de controvérsias do GATT, pois acarretava em uma demora excessiva do processo.

O sistema de solução de controvérsias do GATT, portanto não era eficaz, visto que não previa prazo fixo, era facilmente obstruído, e o funcionamento dos painéis era demorado, com a elaboração de relatórios que muitas vezes não eram aprovados pelo Conselho do GATT ou eram facilmente obstruídos pelo Estado vencido.

\subsubsection{As Rodadas de Negociação do GATT}

No âmbito do sistema de comércio do GATT, entre 1947 e 1995, foram concluídas oito grandes rodadas de negociações multilaterais: Rodada Genebra (1947), Rodada Annecy (1949), Rodada Torquay (1950/51), Rodada Genebra (1955/56), Rodada Dillon (1960/61), Rodada Kennedy (1963/67), Rodada Tóquio (1973/79) e Rodada Uruguai (1986/93). Essas rodadas de negociação serviram para rever, avaliar, discutir e propor regras e normas gerais de comércio.

Nas primeiras cinco rodadas de negociações do GATT tratou-se quase que exclusivamente da questão da redução das tarifas 
aduaneiras. Essas negociações foram extremamente bem sucedidas e levaram a uma redução drástica das tarifas mundiais de produtos manufaturados. Esse período, de 1947 a 1961, é caracterizado, assim, como uma etapa de consolidação e relativo sucesso do processo de liberalização comercial (VALLS, 1997 apud LOW, 1989).

A partir da Rodada Kennedy, no entanto, observou-se importantes mudanças nas negociações sob o regime de comércio do GATT, novos temas e questões foram introduzidos na agenda de negociações e os países em desenvolvimento passaram a exercer um papel mais ativo nessas negociações.

A Rodada Kennedy, de 1963 a 1967, significou o início de uma nova etapa no GATT. Esta foi a primeira vez que a Comunidade Européia participou das negociações como um bloco, equilibrando o poder de barganha entre os participantes. O método de redução linear das tarifas, proposta na Rodada Dillon, pelos países europeus, foi adotado durante essa rodada.

Foi somente a partir da Rodada Kennedy, também, que começaram a serem discutidas outras questões, além da redução de barreiras tarifárias, como as barreiras não-tarifárias e os problemas relacionados ao comércio de produtos agrícolas e, também, a serem negociados um acordo antidumping e algumas disposições em favor dos países em desenvolvimento - com a criação da chamada parte IV do Acordo Geral (REGO, 1996).

$\mathrm{Na}$ chamada parte IV do GATT, reconhecia-se a necessidade de proverem-se condições mais favoráveis e aceitáveis às exportações de produtos primários de países em desenvolvimento, além de acesso ampliado, sob condições favorecidas, aos produtos processados e manufaturados pelos países de menor desenvolvimento econômico. Inicialmente, a parte IV indicava somente a possibilidade do tratamento não recíproco, tal disposição só foi efetivamente revisada e incorporada ao GATT na Rodada Tóquio, pela Cláusula de Habilitação (OLIVEIRA, 2007). 
$\mathrm{Na}$ rodada Kennedy houve uma maior participação dos países em desenvolvimento amparados pelas discussões na Conferência das Nações Unidas sobre Comércio e Desenvolvimento (UNCTAD) e por uma posição política mais de mercado liberal por parte desse grupo de países.

A década de sessenta e o início da década de setenta é um período marcado pela crescente percepção dos países em desenvolvimento da necessidade de uma nova ordem econômica mundial, que permitisse atenuar as diferenças no nível de desenvolvimento entre Norte e Sul. A partir desse período, os países em desenvolvimento passam a demandar dos países desenvolvidos uma efetiva colaboração na melhora da distribuição de renda. Inicia-se, assim, uma nova etapa relativa à participação dos países em desenvolvimento no GATT. Essa nova etapa coincide com a inauguração de uma nova rodada de negociações multilaterais, a Rodada Tóquio, em 1973.

A Rodada Tóquio, de 1973 a 1979, foi realizada, no entanto, em um quadro claramente distinto das rodadas que a antecedera, pois, como descreve Lia Valls "a década de setenta foi caracterizada por importantes mudanças na economia mundial. O Japão e a Comunidade Européia consolidam suas posições como concorrentes dos Estados Unidos no comércio mundial. Os novos países industrializados tornam-se detentores das vantagens comparativas em produtos manufaturados intensivos em mão-de-obra. Avançam as inovações tecnológicas nos chamados novos setores da Terceira Revolução Industrial acirrando a concorrência entre os países desenvolvidos e acelerando o processo de transformação em suas estruturas produtivas. O sistema de taxas de câmbio fixas negociado no pósguerra muda para um sistema de taxas cambiais flutuantes. A crise do petróleo, em 1973, interrompe o ciclo da expansão iniciado no pós-guerra e os países desenvolvidos enfrentam problemas de desemprego estrutural e aceleração inflacionária. Crescem as restrições comerciais praticadas pelos países desenvolvidos, dado o cenário de ajustes na estrutura produtiva e fatores conjunturais recessivos“ (1997, p. 06). 
Em um ambiente econômico conturbado, a Rodada Tóquio foi a primeira grande tentativa de abordar a questão das barreiras nãotarifárias e melhorar o sistema de comércio então vigente. Durante a rodada, cerca de 100 países negociaram reduções tarifárias e outros acordos específicos sobre medidas não-tarifárias (REGO, 1996).

Essa rodada de negociações resultou, assim, em uma grande expansão da atividade e da competência do GATT, não por meio de emendas ao tratado, mas por meio de negociações de uma série de instrumentos separados, chamados de "códigos", cada qual, tecnicamente, um tratado em separado, que visavam regular os procedimentos de várias barreiras não-tarifárias como valoração aduaneira, sistema de licenciamento de importações, barreiras técnicas, compras governamentais, subsídios, diretos compensatórios e antidumping (JACKSON, 1997).

O resultado mais importante gerado nessa rodada foi, provavelmente, a reforma do GATT, com a incorporação efetiva de um tratamento diferencial e mais favorável para países em desenvolvimento, por meio da Cláusula de Habilitação ${ }^{9}$ (OLIVEIRA, 2007). A rodada fracassou, no entanto, em seu intento de normatizar o comércio de produtos agrícolas e de criar um acordo de salvaguardas, frustrando, assim, interesses de países em desenvolvimento, como o Brasil (REGO, 1996).

Independentemente de seus sucessos e fracassos, a Rodada Tóquio significou a colocação de problemas que induziram ao questionamento dos princípios e da estrutura do GATT (VALLS, 1997).

Em 1982, começaram as conversas para o lançamento de uma nova rodada de negociações, no âmbito do GATT. Durante as negociações para a nova rodada verificou-se a diversidade de interesses entre os países desenvolvidos e os em desenvolvimento. "De um lado, os países desenvolvidos pressionavam pela inclusão de novos temas. Por outro

\footnotetext{
9 "Enabling Clause": Cláusula por meio da qual os países desenvolvidos estão habilitados a conceder tratamento diferenciado e mais favorável aos países em desenvolvimento (PEDs) e, simultaneamente, a não esperar por reciprocidade desses países (PEDs) nos compromissos assumidos ao longo das negociações.
} 
lado, os países em desenvolvimento consideravam que esta inclusão tenderia a relegar ao segundo plano a questão da proliferação de barreiras não-tarifárias, ou seja, a ausência de aderência às regras já estabelecidas no GATT" (VALLS, 1997, p. 08).

O consenso necessário para o lançamento de uma nova rodada só foi alcançado, em 1986, na reunião ministerial de Punta Del Este, no Uruguai, ficando acordado que tantos temas pendentes (como agricultura, têxteis, subsídios) quanto novos temas (como serviços, propriedade intelectual, investimentos) seriam negociados.

Nesse contexto, a última e mais longa de todas as rodadas do GATT, a Rodada Uruguai, levou a criação da OMC e a adoção de novos acordos na área de comércio (como TRIPS, TRIMS e GATS), iniciando, assim, uma nova etapa no sistema multilateral de comércio.

A OMC substituiu o GATT, como organização internacional, no entanto, o GATT ainda existe como acordo "guarda-chuva" da OMC para o comércio de bens (GATT 1994).

As Rodadas de Negociações Comerciais do GATT

\begin{tabular}{|c|c|c|c|}
\hline Ano & Local/(Nome) & Assuntos Cobertos & Países \\
\hline 1947 & Genebra & Tarifas & 23 \\
\hline 1949 & Annecy & Tarifas & 13 \\
\hline 1951 & Torquay & Tarifas & 38 \\
\hline 1956 & Genebra & Tarifas & 26 \\
\hline $1960-1961$ & Genebra / (Rodada Dillon) & Tarifas & 26 \\
\hline $1964-1967$ & Genebra / (Rodada Kennedy) & Tarifas e medidas antidumping & 62 \\
\hline $1973-1979$ & Genebra / (Rodada Tóquio) & $\begin{array}{c}\text { Tarifas, medidas não tarifárias } \\
\text { e acordos jurídicos. }\end{array}$ & 102 \\
\hline $1986-1994$ & Genebra / (Rodada Uruguai) & $\begin{array}{c}\text { Tarifas, medidas não tarifárias, } \\
\text { normas, serviços, propriedade } \\
\text { intelectual, têxteis, agricultura, } \\
\text { solução de controvérsias, } \\
\text { criação da OMC etc. }\end{array}$ & 123 \\
\hline
\end{tabular}

Fonte: OMC, 2009. 


\subsubsection{Rodada Uruguai}

A Rodada do Uruguai, de 1986 a 1993, mostrou-se a mais difícil, contenciosa, complexa e ambiciosa rodada de negociações realizada sob os auspícios do GATT. Por meio da rodada, os países contratantes do GATT pretendiam estender o sistema comercial para novas áreas, principalmente, no setor de serviços, de propriedade intelectual, de agricultura e de têxteis. Lançada em Punta Del Este, as negociações da rodada desdobraram-se em Montreal, Bruxelas, Genebra e Marrakesh.

No começo da Rodada Uruguai, era consenso geral que o objetivo principal das negociações era restaurar a confiança no sistema multilateral de comércio do GATT. A razão dos governos terem sentido a necessidade de revitalizar o sistema foi o descompasso entre o regime do GATT e a direção que a economia mundial tomava no início da década de1980.

Em Punta Del Este, em 1986, adotou-se, pela primeira vez, a idéia do single undertaking ${ }^{10}$ nas negociações do comércio de bens, na qual ou o país aceitaria todos os dispositivos negociados ou nada. $\mathrm{Na}$ reunião ministerial de Montreal, em 1988, acordos preliminares foram alcançados em produtos tropicais, têxteis, propriedade intelectual, salvaguardas, melhoria no mecanismo de solução de controvérsias, além de um acordo-base na área de serviços. O impasse na área agrícola, no entanto, continuou (OLIVEIRA, 2007).

\footnotetext{
10 "O "single undertaking" (ou compromisso único) consiste na negociação de um único pacote de objetivos, ou na negociação de vários objetivos de forma única. Todos os acordos multilaterais da OMC são negociados dessa forma. Na prática, isso implica que enquanto não houver definição para algum dos pontos negociados, nada estará acordado de forma definitiva. Esta foi a principal inovação institucional da Rodada Uruguai, que ajudou a superar problemas de reciprocidade dentro sistema multilateral de comércio. Ressalte-se que o "single undertaking" não se aplica aos acordos plurilaterais no âmbito da OMC, posto que não é obrigatória a adesão dos seus membros a esses acordos".(ICONE. Disponível em: < http://www.iconebrasil.org.br/pt/?actA=16\&arealD=14\&secaolD=29\&letraVC=S $>$. Acesso em: 05 de abril de 2009.
} 
As negociações agrícolas, embora o Grupo de Cairns ${ }^{11}$ tenha tentado participar de forma ativa, tomaram forma de discussão bilateral, entre os EUA e a Comunidade Européia, sobre o processo de liberalização do comércio desse setor e a redução dos subsídios internos (OLIVEIRA, 2007). Prejudicadas, pelo fato de não haver um acordo entre os Estados Unidos e a União Européia, nessa área, as negociações da Rodada Uruguai entraram em colapso durante a reunião ministerial de Bruxelas, em 1990.

Somente em 1992, em Genebra, deu-se prosseguimento as negociações da Rodada Uruguai, com a assinatura, entre os Estados Unidos e União Européia, do acordo de "Blair House", por meio do qual resolveram a maior parte de suas pendências em agricultura, desconsiderando totalmente as demandas do Grupo de Cairns.

Depois de idas e vindas, em 1993, em Genebra, as negociações da Rodada Uruguai foram finalmente concluídas, deixando em aberto, para negociações futuras, algumas questões mais controversas, nas quais não se conseguiu consenso para fechar as negociações, como as cláusulas sociais e ambientais. Por fim, em 1994, em Marrakesh, assinou-se a Ata Final da Rodada Uruguai, por meio da qual se criou a Organização Mundial de Comércio (OMC).

De forma resumida, foram os principais resultados da Rodada Uruguai: a) o corte médio de $37 \%$ das tarifas de importação internacionais; b) a reincorporação dos produtos agropecuários ao sistema multilateral de comércio (SMC); c) a incorporação dos produtos têxteis ao SMC; d) aumento percentual das linhas de produtos consolidadas (registradas na OMC); e) inclusão do setor de serviços no SMC - GATS; f) Garantia de proteção aos direitos de propriedade intelectual relacionados

\footnotetext{
${ }^{11}$ Grupo de Cairns é uma organização composta por 19 países: Argentina, Austrália, Bolívia, Brasil, Canadá, Chile, Colômbia, Costa Rica, Guatemala, Indonésia, Malásia, Nova Zelândia, Paquistão, Paraguai, Peru, Filipinas, África do Sul, Tailândia e Uruguai. Juntos, os países-membros são responsáveis por mais de $25 \%$ das exportações mundiais de produtos agrícolas.
} 
com o comércio - Acordo sobre os Direitos de Propriedade Intelectual Relacionados com o Comércio (TRIPS); g) Aperfeiçoamento dos instrumentos de defesa comercial, com a negociação de um acordo sobre salvaguardas e o aperfeiçoamento dos códigos sobre subsídios e medidas antidumping; h) Criação de um novo sistema de solução de disputas comerciais - Entendimento de Solução de Controvérsias (ESC) (REGO, 1996).

A Rodada Uruguai foi a última rodada de negociações multilaterais promovida no âmbito do GATT. Finalizada oficialmente, em 1994, em Marrakesh, no Marrocos, a Rodada Uruguai estabeleceu, assim, um novo paradigma no sistema multilateral de comércio, tanto pela incorporação de negociações de áreas além de mercadorias (serviços, propriedade intelectual), quanto pela criação da Organização Mundial do Comércio (OMC).

\subsection{Criação da Organização Mundial de Comércio}

Sucessora do GATT, a Organização Mundial do Comércio (OMC) é a organização central do sistema multilateral de comércio criada para coordenar e administrar questões referentes ao comércio internacional. Criada ao final da Rodada Uruguai, entrou em funcionamento em 1 de janeiro de 1995.

A transformação do GATT na OMC, ao fim da Rodada Uruguai, foi uma tentativa ambiciosa de constitucionalizar regras comerciais internacionais, instituições e processos de decisão. Com a criação da OMC, o comércio internacional ingressou em uma nova fase, com maiores direitos e deveres para praticamente todos os países.

A OMC foi instituída com o objetivo de assegurar que o comércio mundial flua o mais calmo, previsível e livre possível, garantindo, assim, um mundo mais pacífico, próspero e justo para todos. Em comparação ao sistema de comércio centralizado no GATT, não só foi dada 
a OMC responsabilidades em novas áreas do comércio, como agricultura, serviços, têxteis e propriedade intelectual, como se criou um novo sistema vinculante de solução de disputas, assegurando aos membros da organização melhor proteção de seus direitos.

A OMC é o foro multilateral responsável pela regulamentação do comércio internacional. Suas atribuições incluem: (i) negociar regras para o comércio internacional de bens, serviços, propriedade intelectual e outras matérias que os Membros venham a acordar; (ii) zelar pela adequada implementação dos compromissos assumidos; (iii) servir de espaço para a negociação de novas disciplinas; e (iv) resolver controvérsias entre os Membros ${ }^{12}$.

A OMC opera um sistema de regras de comércio. Seus pilares de sustentação são os acordos da OMC, entre eles o GATT, GATS, TRIPS, negociados e firmados pela maioria dos países que participam do comércio mundial e ratificados por seus respectivos parlamentos.

Atualmente, a OMC possui 153 membros, Cabo Verde foi o último país a ingressar na organização, em julho de 2008. Cerca de dois terços dos 150 membros da OMC são de países em desenvolvimento. A sede da instituição localiza-se em Genebra e fazem parte do seu quadro de funcionários cerca de 625 pessoas. Desde setembro de 2005, Pascal Lamy ocupa o cargo de Diretor Geral - cargo máximo da organização. O orçamento para 2009 é de 189 milhões de francos suíços ${ }^{13}$.

\subsubsection{Estrutura Institucional da OMC}

A OMC tem a função de administrar os acordos comerciais entre seus membros, ser um fórum para negociações, direcionar as disputas comerciais, fazer o monitoramento de políticas comerciais nacionais, dar

\footnotetext{
${ }^{12}$ MRE. Organização Mundial de Comércio. Disponível em: http://www.mre.gov.br/index.php?option=com content\&task=view\&id=2040\&/temid=59. Acesso em: 03 de abril de 2009.

${ }^{13}$ WTO. Disponível em: < http://www.wto.org/english/thewto e/thewto e.htm>. Acesso em: 05 de abril de 2009.
} 
assistência técnica e treinamento aos países em desenvolvimento e cooperar com outras organizações internacionais. Sua estrutura institucional é um tanto complexa e funciona em quatro níveis organizacionais, como se pode observar, abaixo, pela ilustração simplificada do organograma da OMC:

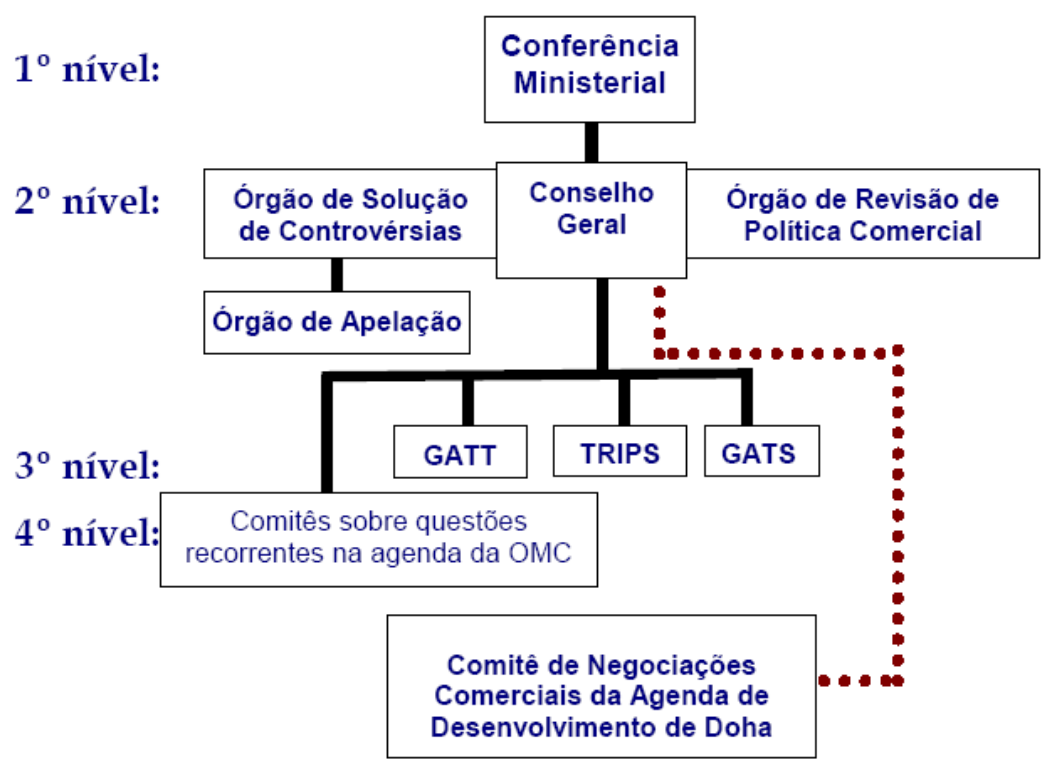

Fonte: OMC, 2009 (organograma simplificado)

No ápice da estrutura institucional da OMC está a Conferência Ministerial. As Conferências Ministeriais são realizadas, no mínimo, a cada dois anos e reúnem todos os membros da OMC. Nelas são definidos os temas que serão tratados em cada rodada de negociação. Essa instância é composta por Ministros das Relações Exteriores e/ou Ministros de Comércio Exterior dos países membros. O processo de decisão, como era no GATT, é por consenso.

Em um patamar abaixo da Conferência Ministerial encontram-se três organismos: O Conselho Geral, o Órgão de Solução de Controvérsias e o Órgão de Revisão de Política Comercial. O Conselho Geral da OMC é um órgão permanente, que formado por embaixadores ou chefes de delegações de todos os países membros, reúne todos os membros da OMC. Sua função é zelar pelo cumprimento dos Acordos 
Multilaterais, administrar as atividades diárias da OMC e executar as decisões das conferências ministeriais, assumindo suas funções, nos intervalos entre as reuniões. Quando apropriado o Conselho Geral convertese no Órgão de Solução de Controvérsias ou no Revisor de Políticas Comerciais (KUFUOR, 2004).

Subordinado ao Conselho Geral, além de alguns comitês e grupos de trabalho, há ainda três conselhos: o conselho para o comércio de bens (GATT), o conselho para o comércio de serviços (GATS) e o conselho para o comércio relacionado aos aspectos da propriedade intelectual (TRIPS). Esses conselhos são responsáveis pelo planejamento, implementação e funcionamento dos tratados nos seus respectivos assuntos. O Comitê de Negociações Comerciais da Agenda de Desenvolvimento de Doha possui, também, um vínculo direto com o Conselho. Geral

Além do Conselho Geral há ainda dois outros órgãos que o auxiliam em seus trabalhos. O Órgão de Solução de Controvérsias (OSC) que, composto por todos os membros da organização, é a instituição máxima do sistema de solução de controvérsias e o Órgão de Revisão de Política Comercial (ORPC) que tem a função de revisar as políticas comerciais de seus membros e com isso contribuir para uma maior adesão dos mesmos às regras da instituição, à sua disciplina e aos compromissos assumidos nos acordos multilaterais.

A Secretaria da OMC, localizada em Genebra, é comandada por um Diretor Geral assistido por quatro delegados, sendo que cada divisão da OMC posiciona-se abaixo de um desses delegados ou do Diretor Geral.

\subsubsection{Sistema de Solução de Controvérsias da OMC}

O Sistema de Solução de Controvérsias é o pilar central do sistema multilateral de comércio e a contribuição singular da $\mathrm{OMC}$ à 
estabilidade da economia global. O procedimento da OMC traz segurança, celeridade e previsibilidade ao sistema de comércio.

A sistemática de solução de controvérsias da OMC - o Entendimento de Solução de Controvérsias $(E S C)^{14}$ - é fruto das negociações efetivadas na Rodada Uruguai e está contemplado no Anexo 2 do Tratado de Marrakesh. A eficácia do mecanismo previsto no ESC baseiase em três características: abrangência (inclusão de todos os acordos da OMC), automaticidade (interrupção do processo somente por acordo das partes) e exeqüibilidade (direito de retaliação).

O procedimento de resolução de controvérsias na OMC, caracterizado pelo alto grau de institucionalização, dividi-se, basicamente em quatro fases: consultas, painéis, apelação e implementação.

$\mathrm{Na}$ fase de consultas, fase preliminar e obrigatória do processo de solução de controvérsias, comunica-se a outra parte sobre a possibilidade de uma disputa e busca-se chegar a um acordo. Caso não se chegue a um acordo, pleiteia-se o estabelecimento de um painel ao órgão de solução de controvérsias (OSC) ${ }^{15}$. A OSC reforça o caráter jurisdicional dos procedimentos surgidos com o GATT.

Apesar das empresas comuns e ONG's não poderem recorrer diretamente à $\mathrm{OMC}$, é importante frisar a influência que essas impõem aos Estados onde estão situadas. Um bom exemplo foi o conflito entre Embraer e Bombardier entre 1998 e 2003 (onde cada uma das empresas se fez representar pelo seu país).

A fase do painel funciona de forma semelhante a um tribunal e é considerada a $1^{\mathrm{a}}$ instância do $\mathrm{OSC}^{16}$. O painel é geralmente composto

\footnotetext{
${ }^{14}$ Dispute Settlement Understanding (DSU)

${ }^{15}$ Dispute Setllement Body (DSB)

16 "O Órgão de Solução de Controvérsias (OSC) da OMC é o órgão competente para decidir sobre questões e conflitos relacionados com o comércio internacional entre os membros da OMC, sendo ele composto por todos os membros da organização. Uma das principais funções do OSC é a adoção de relatórios (decisões) dos Painéis e do Órgão de Apelação. A adoção de tais relatórios é baseada na regra do consenso negativo, ou seja, os relatórios somente deixam de ser adotados (i.e, não se tornam mandatórios para as partes), se todos os membros do OSC decidirem, consensualmente (incluindo a parte "vencedora"),
} 
por três e, excepcionalmente, por cinco arbitros, de nacionalidades diferentes das partes em controvérsia, escolhidos pelos membros litigantes. Caso as partes não cheguem a acordo sobre a indicação dos membros do painel, a escolha dos nomes é feita pelo Diretor-Geral da OMC. Estabelecido o painel, ele tem o prazo de seis meses para apresentar o relatório final, no qual profere sua decisão. Um relatório só pode ser rejeitado caso haja consenso entre as partes quanto à rejeição. Caso uma das partes julgue-se insatisfeito com a decisão, pode dela recorrer junto ao Órgão de Apelação da OMC.

O órgão de apelação é a segunda instância decisória para a solução de controvérsias no âmbito da OMC. O órgão de apelação é composto por sete juízes de reconhecido saber em comércio internacional, com mandato de quatro anos. A apelação deve ser sempre restrita a questões de direito constantes do relatório e à interpretação jurídica exposada pelos árbitros no painel. Em geral, o processo de apelação não deve levar mais de sessenta dias da data da notificação do órgão de apelação. Caso não seja possível a tomada de decisão nesse prazo, o órgão de apelação deve enviar ao OSC seus motivos, por escrito, pelo atraso e o tempo que considera necessário para a finalização do processo. O processo, em caso nenhum, pode levar mais de noventa dias. Ao órgão de apelação é concedido o poder de sustentar, alterar ou inverter as decisões proferidas pelo painel. O relatório final do órgão de apelação deve ser adotado pelo OSC e aceito incondicionalmente pelas partes nos trinta dias seguintes à sua comunicação.

$\mathrm{Na}$ fase de implementação da decisão, adotado o relatório final do painel ou do órgão de apelação pelo OSC, a parte afetada deverá informar ao OSC suas intenções de implementação das recomendações e das resoluções previstas no relatório. Na impossibilidade de implementação

recusar sua adoção. Ao OSC também cabe, entre outras funções, receber as notificações acerca de pedidos de consultas, estabelecer Painéis e decidir sobre a participação de terceiras-partes nas controvérsias. O OSC é geralmente presidido por um Chefe de Missão (Embaixador) junto à OMC" (ICONE. Disponível em: http://www.iconebrasil.org.br/pt/?actA=16\&arealD=14\&secaolD=29\&palavralD=377\#377. Acesso em 04 de abril de 2009. 
imedida, a parte pode negociar um prazo para tais providências. O OSC supervisionará a implementação e definirá os instrumentos de supervisão para assegurar o cumprimento da decisão. Em caso de não-cumprimento das recomendações e resoluções, em prazo razoável, cabe recurso à sistemática de compensação de concessões e outras obrigações. Como medida cautelar, o OSC pode autorizar a suspensão de concessões tarifárias e/ou pagamento de indenizações.O OSC deve pronunciar-se a respeito no prazo de trinta dias, contados da expiração do prazo razoável. Divergências quanto ao montante da indenização ou quanto a supensão de concessões tarifárias podem ser definidas pelas partes ou submetido a arbitragem, que deverá ocorrer no prazo de sessenta dias, contados a partir da expiração do prazo razoável (MARTINS, 2004).

Um dos grandes avanços no sistema da OMC, em relação ao sistema do GATT, foi a substituição do consenso positivo, pelo consenso negativo. Assim, no âmbito da OMC, as recomendações e resoluções do painel só não são aprovadas pelo OSC se todos os membros, inclusive o que foi vencedor, decidirem pela não aplicação da decisão do painel.

Outros importantes avanços do sistema de solução de controvérsias da OMC foram a possibilidade de aplicação de retaliações econômico-comerciais aos Estados membros que não cumprirem as recomendações e resoluções do painel ou do órgão de apelação e a fixação de prazos rígidos para as fases do procedimento, que deram efetividade e celeridade ao sistema.

\subsubsection{Conferências Ministeriais da OMC}

No âmbito da Organização Mundial de Comércio, já ocorreram seis conferências ministeriais: Cingapura (1996), Genebra (1998), Seattle (1999), Doha (2001), Cancun (2003), Hong Kong (2005).

Em 1996, na $1^{\text {a }}$ Conferência Ministerial da OMC, em Cingapura, buscou-se reforçar o papel da organização como instância de 
negociações e de busca da liberalização do comércio no quadro de um sistema fundado em regras bem definidas. Durante a Conferência de Cingapura, quatro novos temas foram introduzidos na agenda da OMC: investimentos, políticas de concorrência, transparência em compras governamentais e facilitação de comércio. Esses temas ficaram conhecidos como "temas de Cingapura".

Em 1998, a Conferência de Genebra ficou marcada pela comemoração dos cinqüenta anos da formação do sistema multilateral de comércio. Durante a reunião, acrescentou-se o comércio eletrônico à programação de trabalho da organização e deu-se início às preparações sobre a possibilidade de se realizar negociações mais abrangentes no futuro.

A Conferência de Seattle, em 1999, marcou definitivamente a existência da OMC. O Objetivo da conferência era alcançar um compromisso mínimo para formar uma agenda de temas para uma nova rodada, chamada Rodada do Milênio. A reunião, no entanto, foi suspensa, por não ter sido possível chegar a um consenso a respeito de uma agenda de negociações. Marcaram a conferência o impasse nas negociações e os diversos protestos e manifestações contra o encontro da OMC, que ficaram conhecidos como Batalha de Seattle ou N-30. O consenso geral, ao final do encontro, contudo, era que o fracasso de Seattle não poderia transformar-se no fracasso da OMC.

Assim, após o fracasso de Seattle, os governos estavam determinados a superarem suas diferenças e trabalharem juntos para fazerem do comércio, um instrumento de desenvolvimento mundial. $\mathrm{Na}$ Conferência Ministerial de Doha, em 2001, lançou-se, desse modo, uma nova rodada de negociações, a primeira sob os auspícios da OMC, que ficou conhecida como Rodada Doha para o desenvolvimento, com previsão de encerramento para 1 de janeiro de 2005. O prazo de conclusão, no entanto, foi perdido. 
Na quinta Conferência Ministerial que ocorreu em Cancun, em 2003, apesar de intensas as negociações, as discussões foram muito controvertidas e o acordo para a conclusão da rodada não foi alcançado. $\mathrm{Na}$ questão agrícola, a Conferência em Cancun trouxe à tona a participação do G-20 como interlocutor importante nas negociações.

Em 2004, os países membros da OMC reuniram-se e apresentaram o chamado "Pacote de Julho de 2004", pelo qual chegaram a um acordo sobre a agenda de negociações futuras da organização, eliminando do programa de trabalho os novos temas lançados em Ciingapura ("temas de Cingapura").

Na sexta e ultima Conferência Ministerial realizada, em Hong Kong, em 2005, foi aprovado "O Manifesto dos Ministros de Hong Kong", por meio do qual se obteve grandes resultados no comércio de produtos agrícolas, no acesso ao mercado de produtos não-agrícolas, nos serviços e no debate sobre desenvolvimento. O principal resultado do manifesto foi o compromisso dos países desenvolvidos em abolir os subsídios de todos os produtos agrícolas até o final de 2013.

\subsubsection{Rodada Doha para o Desenvolvimento}

A Rodada Doha, ou Agenda Doha de Desenvolvimento, é resultado da IV Conferência Ministerial da OMC, realizada em Doha, no Catar, em novembro de 2001. Durante a conferência, adotou-se uma agenda de trabalho muito extensa e complexa, que abrange nada mais que 21 temas, que vão desde comércio de bens agrícolas e de bens de serviços, até meio-ambiente, entendimento de solução de controvérsias (ESC), propriedade intelectual.

O tema desenvolvimento logrou alcançar, nessa conferência, uma relevância sem precedentes. Na Declaração Ministerial de Doha, estabeleceu-se, assim, que o comério internacional tem um papel importante 
na promoção do desenvolvimento econômico e na redução da pobreza, como observa-se pelo excerto abaixo:

"O comércio internacional tem condições para desempenhar um importante papel na promoção do desenvolvimento econômico e na diminuição da pobreza. Reconhecemos a necessidade de todos os nossos povos se beneficiarem do aumento de oportunidades e da prosperidade gerados pelo sistema multilateral de comércio [...] continuaremos nossas iniciativas concretas, planejadas para garantir que os países em desenvolvimento, e especialmente os menos desenvolvidos dentre eles, assegurem a sua parcela de participação no crescimento do comércio mundial, proporcional às necessidades de suas economias em expansão. Nesse contexto, acesso favorecido ao mercado, regras equânimes, assistência técnica com financiamento sustentável e objetivos bem formulados, e programas de capacitação têm importante função a cumprir". (OLIVEIRA, 2007, p. 46 Apud CONFERÊNCIA MINISTERIAL DA ORGANIZAÇÃO MUNDIAL DO COMÉRCIO, 2001, p. 1).

Assim, "a retórica desenvolvimentista em prol dos países menos avançados foi a base de lançamento da Rodada, apontando para o tema agrícola como pilar fundamental das negociações" (OLIVEIRA, 2007, p. 45). Esse, inclusive, foi o motivo pelo qual se deu a essa rodada o nome de Agenda Doha de Desenvolvimento. No entanto, "não obstante a liberalização do comércio agrícola seja considerada como elemento central da Rodada, novas negociações acerca de diversos outros temas (como serviços, produtos não agrícolas (NAMA), propriedade intelectual, investimentos, comércio eletrônico etc.) foram também lançadas em Doha, buscando uma óbvia harmonização de interesses entre os países em desenvolvimento e os países desenvolvidos" (OLIVEIRA, 2007, p. 45).

Essa diversidade de temas foi o maior impasse nas primeiras negociações desta rodada. A Conferência Ministerial de Cancún acabou fracassando em virtude da divergência em alguns pontos que evitaram acordos em questões essenciais da rodada. Na Conferência de 
Hong Kong, conseguiu-se um aparente avanço nas negociações, contudo, apesar de todas as expectativas, novamente, não se chegou a um acordo para a conclusão da rodada.

Diante do impasse nas negociações da rodada, o Diretor Geral da OMC, Pascal Lamy, suspendeu as negocidações em julho de 2006. Em reunião crucial, para o destravamento das negociações da rodada, realizada em Genebra, em julho de 2008, os ministros de 35 países, liderados pelos EUA, UE e G-20, reuniram-se na tentativa de se alcançar um acordo de liberalização do comercio mundial no âmbito da Rodada Doha. Diante dos interesses contraditórios dos países desenvolvidos e dos países em desenvolvimento, no entanto, a reunião fracassou.

Não obstante tenha ocorrido alguma aproximação entre as propostas dos principais grupos interessados no tema agrícola desde o início das negociações, o mesmo continuou a ser tanto o foco principal do mandato negociador de Doha, quanto o elemento mais controverso e de complexa negociação da Rodada. Por um lado, os EUA e a União Européia, assim como outros países desenvolvidos, continuam bastante reticentes quanto aos seus pontos mais sensíveis na negociação agrícola. Os países do G-20, de outro lado, buscam maior abertura dos mercados agrícolas dos países desenvolvidos para seus produtos, mas são um tanto relutantes na abertura de setores industriais e de serviços. Tudo isso sem falar em certa esquizofrenia do próprio G-20, em que existem desde países com posicionamentos agressivos em todas as frentes agrícolas, como o Brasil, a economias que buscam posicionamentos claramente protecionistas, como a Índia. Tais posicionamentos discrepantes entre os principais atores das negociações agrícolas na OMC são os principais responsáveis pela paralisação da rodada (OLIVEIRA, 2007).

As negociações da Rodada Doha estão previstas para serem retomadas em julho desse ano (2009). E um avanço em suas negociações é essencial, não só para o futuro do sistema multilateral de 
comércio da OMC, como também para a solução da crise financeira atual, por meio da estimulação do comério mundial .

\subsection{Principais Diferenças entre o GATT e a OMC}

"A OMC não é apenas um GATT ampliado" (REGO, 1996, p.10). Enquanto o GATT foi, durante seus quase 50 anos de existência, um acordo "provisório" entre países, sem base institucional, a OMC é uma organização dotada de personalidade jurídica própria, com o mesmo status do BIRD e do FMI. Enquanto a OMC tem países membros (é uma organização), o GATT era formado apenas por "partes contratadas" (era um acordo). Enquanto no âmbito do GATT, as negociações eram centradas basicamente no comércio de bens, na OMC as negociações cobrem também o comércio de serviços (GATS) e propriedade intelectual (TRIPS).

Desde sua criação, o GATT contribuiu efetivamente para a remoção de barreiras comerciais, porém, nunca teve poder suficiente para impedir que alguns de seus signatários se desviassem por caminhos protecionistas. Isso se deveu, em grande parte, à fragilidade de seus mecanismos de solução de controvérsias, extremamente suscetíveis a bloqueios (REGO, 1996).

Uma das diferenças mais significativas entre a OMC e o GATT envolve exatamente o processo de resolução de controvérsias. O sistema de solução de controvérsias da OMC é mais efetivo e menos sujeito a bloqueios. Sob o GATT, o procedimento para resolver disputas não tinha prazos determinados, sentenças eram fáceis de bloquear e os casos freqüentemente não eram concluídos.

Ao contrário do GATT, a OMC proíbe a parte que perder a disputa, na determinação de um painel, de impedir a adoção da determinação pela maioria dos membros da OMC (que se reúne formando o Órgão de Solução de Controvérsias). O Órgão de Solução de Controvérsias e o Órgão de Apelação podem determinar que o governo corrija o seu não- 
cumprimento de uma obrigação junto à OMC e pode autorizar o governo queixoso a tomar medidas de retaliação na área comercial.

Os acordos do GATT eram, em grande parte, plurilaterais, ao passo que os da OMC são, em sua maioria, multilaterais., ou seja subscritos integralmente por seus membros. Ademais, os acordos multilaterais da OMC são mandatários, no sentido que impõem obrigações a todos seus membros, diferentemente da prática adotada no GATT, no qual as partes contratantes podiam decidir quais acordos iriam aderir.

Pode-se concluir por esse capítulo que houve uma grande e importante evolução do sistema multilateral da instauração do GATT, em 1948, à criação da OMC, em 1995, não só na estrutura institucional do sistema, como também no seu sistema de solução de controvérsias, nos seus processos de negociação e em várias outras áreas. Com a criação da OMC, a estrutura institucional foi ampliada, o sistema de solução de controvérsias tornou-se mais ágil e eficaz e os processos de negociação efetivamente mais democráticos (com a maior participação dos países em desenvolvimento nas negociações). A Rodada Doha - a primeira rodada de negociações sob a égide da OMC - é o melhor exemplo da nova fase do sistema multilateral de comércio, pois, observa-se tanto a introdução, na rodada, de temas de interesse-chave dos países em desenvolvimento, quanto a grande participação desses países nas negociações. 


\section{CONCLUSÃO}

.Nos últimos sessenta anos viu-se um crescimento extraordinário do comércio mundial. O comércio total em 2000 era 22 vezes o de $1950^{17}$. Do período que se estende de 1948, em Havana, com a instauração do GATT, até os dias atuais, houve uma grande evolução do regime internacional de comércio. O GATT e a OMC ajudaram a criar um sistema multilateral de comércio forte e próspero, contribuindo para um crescimento econômico e uma expansão do comércio mundial sem precedentes.

O GATT, apesar de instituído como um acordo provisório, forneceu as regras para o sistema de comércio por quase cinco décadas e foi o principal responsável pela ampla liberalização do comércio mundial observada no período. No entanto, estruturado no âmbito de uma ordem econômica dominada pelos Estados Unidos, o Acordo Geral atendeu basicamente aos interesses das economias desenvolvidas, ignorando, quase por completo, as reivindicações dos países periféricos.

Essa situação só começou a mudar, de fato, a partir da Rodada Tóquio, quando o regime de comércio centralizado no GATT já se encontrava em declínio. O sistema multilateral de comércio, sob a égide do GATT, foi um sistema que proporcionou grande crescimento da economia mundial, porém, de forma desigual, o que acentuou o hiato existente entre os países desenvolvidos e os países em desenvolvimento.

Sob um novo cenário econômico e político, a Organização Mundial de Comércio foi criada, ao final da Rodada Uruguai, não só para corrigir essa e outras deficiências do GATT, como também para adaptar o sistema multilateral de comércio às mudanças geradas nas relações econômicas internacionais pelo fenômeno da globalização.

${ }^{17}$ WTO. Disponível em:< www.wto.org $>$. Acesso em: 28 de março de 2009. 
A OMC foi instituída com o objetivo principal de assegurar que o comércio mundial flua o mais calmo, previsível e livre possível, garantindo, assim, um mundo mais pacífico, próspero e justo para todos. $\mathrm{O}$ lançamento da Rodada Doha, em 2001, demonstrou o interesse da organização na promoção de um sistema de comércio mais igualitário, ao reconhecer a vulnerabilidade dos países menos desenvolvidos e ao colocar no centro das negociações temas de grande relevância para os países em desenvolvimento, como a questão do acesso ao mercado de produtos agrícolas. A promoção do desenvolvimento é inclusive o principal objetivo da rodada.

Constantes divergências entre países desenvolvidos e em desenvolvimento, no entanto, tem atrasado a conclusão das negociações, que estava prevista inicialmente para ser encerrada em 2005. O sucesso da Rodada Doha é de extrema importância para o futuro da Organização Mundial de Comércio, pois, caso seja alcançado o acordo proposto nessa rodada, criar-se-á um sistema multilateral mais equilibrado e justo. Em caso de fracasso, contudo, acredita-se que os avanços conquistados na liberalização do comercio mundial tendem a retroceder, especialmente em face da desaceleração da economia mundial, causada pela atual crise financeira internacional.

Não se sabe ao certo qual será o futuro do sistema multilateral de comércio diante do impasse nas negociações da Rodada Doha e da atual crise financeira internacional. É consenso entre os países do globo, contudo, que o avanço da Rodada Doha é extremamente necessário para estimular o crescimento econômico global e buscar-se, assim, uma solução para crise internacional. 


\section{BIBLIOGRAFIA}

BARRAL, Welber. O Brasil e a OMC. 2 ed. Curitiba: Editora Juruá, 2005.

BRASIL. Ministério das Relações Exteriores. Carta de Genebra: Informativo sobre a OMC e a Rodada Doha. Ano 1, Vol. 1, Fevereiro de 2002. Disponível em: <http://www.mre.gov.br/carta_genebra/cartadegenebra1.pdf>. Acesso em: 01 de abril de 2009.

BRASIL. MRE. Organização Mundial de Comércio. Disponível em: http://www.mre.gov.br/index.php?option=com_content\&task=view\&id=2040\&l temid=59. Acesso em: 03 de abril de 2009.

BRASIL. Ministério das Relações Exteriores. G-20. Disponível em < http://www.g-20.mre.gov.br/history_port.asp>. Acesso em: 22 de março de 2009.

GONÇALVES, Reinaldo. O Brasil e o comércio internacional: transformações e perspectivas. São Paulo: Contexto, 2000.

ICONE. Disponível em: <www.iconebrasil.org.br>. Acesso em 04 de abril de 2009.

ICTSD. Bananas: Uma década na Agenda da OMC. Disponível em: $<$ http://ictsd.net/i/news/4409/>. Acesso em: 03 de abril de 2009.

ICTSD. Bananas: OMC condena regras de importação da UE e Equador ameaça vetar Doha se a questão não for resolvida. Disponível em: $<$ http://ictsd.net///news/pontesquinzenal/35526/>. Acesso em: 03 de abril de 2009.

JACKSON, John H. The World Trading System: Law and Policy of International Economic Relations. 2 ed. Massachusetts Institute of Technology, 1997.

KRASNER, Stephen D. International Regimes. Cornell University Press, 1983.

KUFUOR, Kofi Oteng. World Trade Governance and Developing Countries. The Royal Institute of International Affairs, 2004.

LAMY, Pascal. Rodada Doha é Essencial para o Desenvolvimento no Século XXI. [artigo] Disponível em < http://www.rts.org.br/artigos/rodada-doha-e- 
essencial-para-o-desenvolvimento-no-seculo-xxi/> Acesso em 01 de abril de 2009.

OLIVEIRA, Ivan Tiago M.. A Ordem Econômico-Comercial Internacional: Uma Análise da Evolução do Sistema Multilateral de Comércio e da Participação da Diplomacia Econômica Brasileira no Cenário Mundial. Revista CONTEXTO INTERNACIONAL Rio de Janeiro, vol. 29, no 2, julho/dezembro 2007, p. 217-272. Disponível em < http://www.scielo.br/pdf/cint/v29n2/v29n2a01.pdf > Acesso em 31 de março de 2009.

MACRORY, Patrick F. J., APPLETON, Arthur E. and PLUMMER, Michael G. The World trade Organization: Legal, Economic and Political Analysis. V. 1. Springer Science + Business Media, Inc., 2005.

MACRORY, Patrick F. J., APPLETON, Arthur E. and PLUMMER, Michael G. The World trade Organization: Legal, Economic and Political Analysis. V. 2. Springer Science + Business Media, Inc., 2005.

MACRORY, Patrick F. J., APPLETON, Arthur E. and PLUMMER, Michael G. The World trade Organization: Legal, Economic and Political Analysis. V. 3. Springer Science + Business Media, Inc., 2005.

MARTINS, Eliane Maria Octaviano. A sistemática de solução de controvérsias no âmbito da OMC. Jus Navigandi, Teresina, ano 8, n. 261, 25 mar. 2004. Disponível em: <http://jus2.uol.com.br/doutrina/texto.asp?id=4977>. Acesso em: 04 abr. 2009

REGO, Elba C. L. R. Do GATT à OMC: O que mudou, como funciona e para onde caminha o sistema multilateral de Comércio. [Artigo Científico] Disponível em: <http://www.bndes.gov.br/conhecimento/revista/gatt.pdf> Acesso em: 22 de março de 2009.

SANCHEZ, Inaiê. Para Entender a Internacionalização da Economia. São Paulo: Editora SENAC, 1999.

SANTIAGO, Irma. Os Regimes Internacionais para a Agricultura e a Participação Brasileira no Comércio Internacional. Brasília: Universidade de Brasília, setembro, 2005.

SATO, Eiiti. Mudanças estruturais no sistema internacional: a evolução do regime de comércio do fracasso da OIC a OMC. Disponível em < 
http://www.cedep.ifch.ufrgs.br/Textos_Elet/pdf/DA\%200IC\%20PARA\%200M C\%202001.pdf> Acesso em: 31 de março de 2009.

THORSTENSEN, Vera. Organização Mundial de Comércio: As regras do comércio internacional e a nova rodada de negociações multilaterais. 2 ed. São Paulo: Aduaneiras, 2001.

TREBILCOCK, Michael J., HOWSE, Robert. The Regulation of International Trade. 3 ed. Routledge: Taylor and Francis Book, 2005.

VALLS, Lia. Histórico da Rodada Uruguai do GATT. Rio de Janeiro: UFRJ, 1997. Disponível em

<http://www.ie.ufrj.br/ecex/pdfs/historico_da_rodada_uruguai_do_gatt.pdf>. Acesso em: 01 de abril de 2009.

ZANON JÚNIOR, Orlando Luiz. O caso da gasolina: a soberania e o sistema de resolução de disputas da OMC. Revista de direito econômico internacional: RDEI, n. 6, dez. 1999. Disponível em:

$<$ http://www.iribr.com/rdei/5_ed/gisele_feminella_regis_01.asp\#cap1-3>. Acesso em: 04 de abril de 2009.

WTO. Understanding WTO. Disponível em <

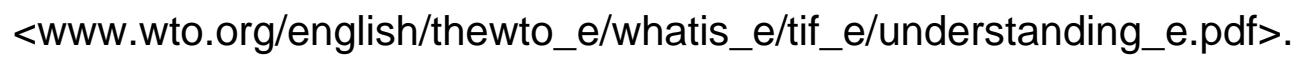
Acesso em 02 de abril de 2009.

WIKIPEDIA. Disponível em: <http://pt.wikipedia.org>. Acesso em: 23 de março de 2009.

WTO. Disponível em: www.wto.org. Acesso em: 23 de março de 2009. 


\section{ANEXOS}

\section{WTO structure}

All WTO members may participate in all councils, committees, etc, except Appellate Body, Dispute Settlement panels, and plurilateral committees.

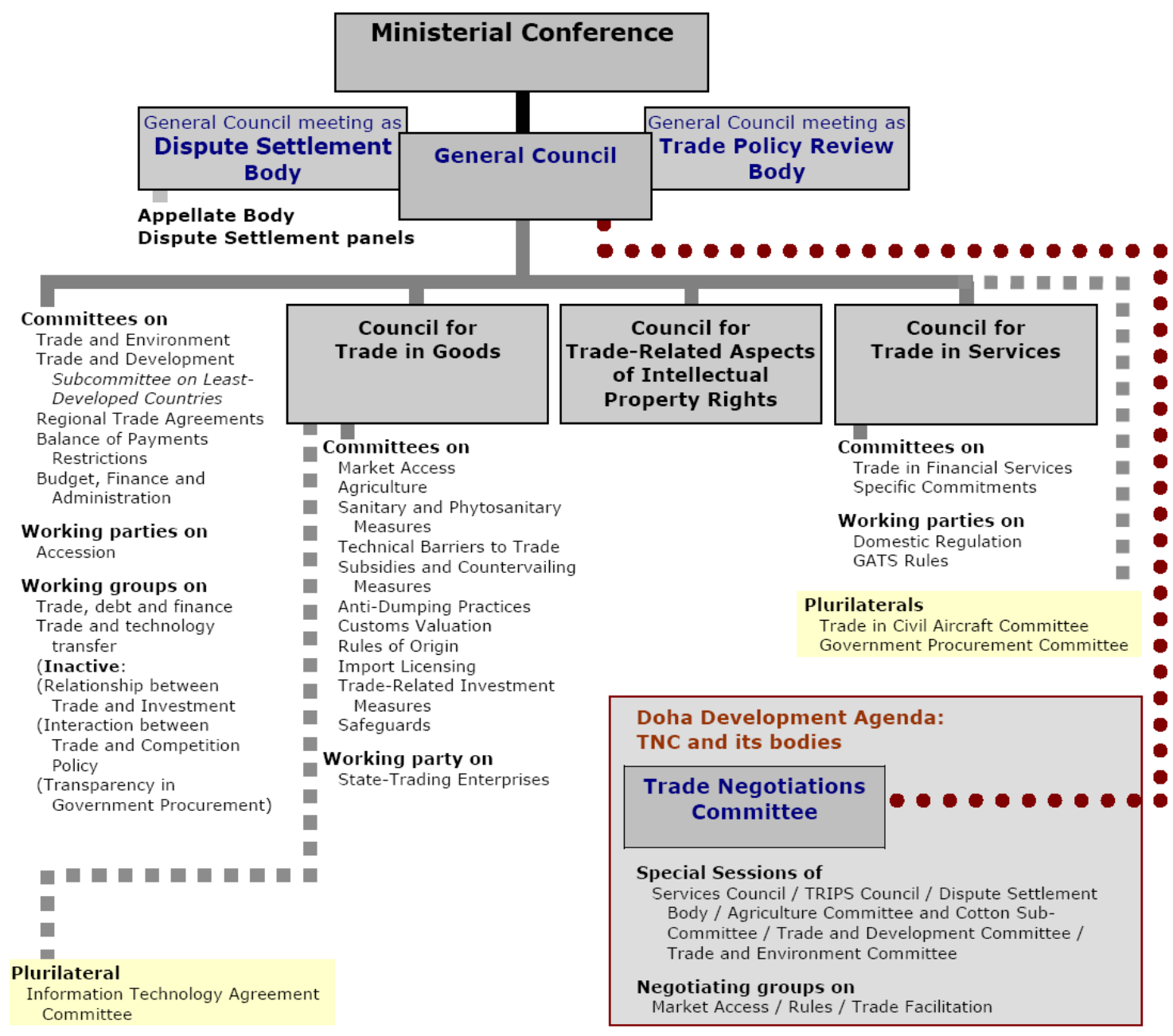

Key

Reporting to General Council (or a subsidiary)

Reporting to Dispute Settlement Body

Plurilateral committees inform the General Council or Goods Council of their activities, although these agreements are not signed by all WTO members

- - Trade Negotiations Committee reports to General Council

The General Council also meets as the Trade Policy Review Body and Dispute Settlement Body 